\title{
PENYULUHAN TENTANG PENYAKIT CACINGAN PADA ANAK-ANAK DAN MASYARAKAT
}

\author{
Miratu Megasari, SST, M.Kes ${ }^{(1)}$, Bela Fiska ${ }^{(2)}$ \\ STIKes Hang Tuah Pekanbaru \\ Email : miratu090586@htp.ac.id
}

\begin{abstract}
ABSTRAK
Sekitar 60 persen orang Indonesia mengalami infeksi cacing. Kelompok umur terbanyak adalah pada usia 5-14 tahun. Angka prevalensi 60 persen itu, 21 persen di antaranya menyerang anak usia SD dan rata-rata kandungan cacing per orang enam ekor. Data tersebut diperoleh melalui survei dan penelitian yang dilakukan di beberapa provinsi pada tahun 2006.

Penyebaran cacing salah satu penyebabnya adalah kebersihan perorangan yang masih buruk. Dan dapat menular diantara murid sekolah yang sering berpegangan tangan sewaktu bermain. Sampai saat ini penyakit cacingan masih merupakan masalah kesehatan masyarakat di Indonesia, terutama daerah pedesaan. Pencegahan infeksi berulang sangat penting dengan membiasakan perilaku hidup bersih dan sehat seperti menghindari kontak dengan tanah yang kemungkinan terkontaminasi feses manusia, cuci tangan dengan sabun dan air sebelum memegang makanan, lindungi makanan dari tanah dan cuci atau panaskan makanan yang jatuh kelantai. Beberapa peneliti ternyata menunjukkan bahwa usia sekolah merupakan golongan yang sering terkena infeksi cacingan karena sering berhubungan dengan tanah (Depkes RI, 2004).

Laporan dari dinas kesehatan kota Pekanbaru salah satu indicator PHBS penyakit cacing disebabkan kebanyakan anak-anak tidak membiasakan diri untuk mencuci tangan mereka dengan bersih karna pengetahuan, kesadaran ibu dan akan kepedulian orang tua terhadap anaknya masih kurang untuk mengajarkan anaknya untuk hidup sehat seperti mencuci tangan dengan air dan sabun. Oleh karena itu maka rumusan masalah pada pengabdian masyarakat ini adalah Memberitahu apa itu penyakit cacing dan cara pencegahannya.

Setelah selesai melakukan penyuluhan ini diharapkan kepada orang tua dan anakanak Puskesmas Simpang Baru dapat memahami tentang penyakit cacingan dan faktorfaktor yang mempengaruhi tentang penyakit cacingan.

Pengendalian penyakit cacingan dapat menurunkan prevalensi dan intensitas penyakit cacingan sehingga dapat menunjang peningkatan mutu sumber daya manusia, guna mewujudkan manusia yang sehat. Program pemberantasan cacingan menghasilkan perbaikan besar baik bagi kesehatan perorangan maupun masyarakat, yaitu dengan bebas penyakit cacingan produktivitas meningkat, dengan berprilaku hidup bersih dan sehat, kita bebas penyakit cacingan, Penyakit cacingan hilang dan prestasi meningkat.
\end{abstract}

\section{Kata Kunci : Balita,Penyakit Cacingan, Puskesmas Simpang Baru Pekanbaru}

\section{PENDAHULUAN}

Sekitar 60 persen orang Indonesia mengalami infeksi cacing. Kelompok umur terbanyak adalah pada usia 5-14 tahun. Angka prevalensi 60 persen itu, 21 persen di antaranya menyerang anak usia SD dan rata-rata kandungan cacing per orang enam ekor. Data tersebut diperoleh 
melalui survei dan penelitian yang dilakukan di beberapa provinsi pada tahun 2006.

Lingkungan hidup menurut Undang-Undang nomor 23 tahun 1997 tentang Pengelolaan Lingkungan Hidup adalah kesatuan ruang dengan semua benda, daya, keadaan dan makhluk hidup, termasuk di dalamnya manusia beserta perilakunya yang mempengaruhi kelangsungan perikehidupan dan kesejahteraan manusia serta makhluk hidup lainnya. Bila ditinjau lebih lanjut mengenai.Undang-Undang tersebut, maka manusia dengan lingkungan sebenarnya tidak dapat dipisahkan. Keadaan sanitasi yang belum memadai, keadaan sosial ekonomi yang masih rendah didukung oleh iklim yang sesuai untuk pertumbuhan dan perkembangan cacing merupakan beberapa faktor penyebab tingginya prevalensi infeksi cacing usus yang ditularkan di Indonesia (Zit, 2000).

Ada 3 jenis cacing yang terpenting adalah cacing gelang (Ascaris lumbricoides), cacing tambang (Ancylostoma duodenale dan Necator americanus) dan cacing cambuk (Trichuris trichura). (Depkes RI, 2004). Ascaris lumbricoides merupakan helmintiasis yang paling sering menyerang anak-anak, cacing ini telah menyebabkan lebih dari satu milyar kasus kecacingan di seluruh dunia. Angka kejadian infeksi Ascaris lumbricoides di Indonesia sebesar $70 \pm 80 \%$, keadaan ini menyebabkan penyakit ascariasis menjadi penting dan hingga saat ini masih merupakan masalah dibidang ilmu kesehatan anak dan kesehatan masyarakat. Penyakit cacingan merupakan salah satu masalah kesehatan di Indonesia. Penyakit cacing ditularkan melalui tangan yang kotor, kuku panjang dan kotor menyebabkan telur cacing terselip.

Penyebaran cacing salah satu penyebabnya adalah kebersihan perorangan yang masih buruk. Dan dapat menular diantara murid sekolah yang sering berpegangan tangan sewaktu bermain. Sampai saat ini penyakit cacingan masih merupakan masalah kesehatan masyarakat di Indonesia, terutama daerah pedesaan. Pencegahan infeksi berulang sangat penting dengan membiasakan perilaku hidup bersih dan sehat seperti menghindari kontak dengan tanah yang kemungkinan terkontaminasi feses manusia, cuci tangan dengan sabun dan air sebelum memegang makanan, lindungi makanan dari tanah dan cuci atau panaskan makanan yang jatuh kelantai. Beberapa peneliti ternyata menunjukkan bahwa usia sekolah merupakan golongan yang sering terkena infeksi cacingan karena sering 
berhubungan dengan tanah (Depkes RI, 2004).

Waspadai dan kenali penyakit cacing pada anak. Penyakit yang sering terjadi ini sangat mengganggu tumbuh kembang anak. Sehingga sangat penting untuk mengenali dan mencegah penyakit cacing pada anak sejak dini. Gangguan yang ditimbulkan mulai dari yang ringan tanpa gejala hingga sampai yang berat bahkan sampai mengancam jiwa. Secara umum gangguan nutrisi atau anemia dapat terjadi pada penderita. Hal ini secara tidak langsung akan mengakibatkan gangguan kecerdasan pada anak.(Depkes RI, 2004).

\section{METODE KEGIATAN}

Melakukan kegiatan penyuluhan dengan mengangkat kan tema " Penyakit Cacingan pada anak-anak" metode yang dilakukan dengan memberikan penyulahan langsung dengan leaflet berisi materiserta Tanya jawab seputar materi.

\section{HASIL DAN PEMBAHASAN}

\section{Hasil Pelaksanaan}

Kegiatan penyuluhan tentang cacingan ini telah dilaksanakan pada tanggal 03 juli 2018. Berdasarkan tanya jawab dan pengamatan langsung selama kegiatan berlangsung, kegiatan pegabdian pada masyarakat ini memberikan hasil sebagai berikut :

1. Meningkatkan pengetahuan dan pemahaman kader tentang hipertensi, dilihat dari kemampuan kader dalam menjawab pertanyaan yang diajukan oleh pemateri

2. Meningkat pengetahuan kader dalam pengendalian penyakit hipertensi, sehingga dimungkinkan kader untuk menjaga pola hidup sehingga terhindar dari hipertensi dan menghindari yang dapat meningkatkan tekanan darah.

3. Meningkatkan pengetahuan kader dalam pengendalian penyakit hipertensi, sehingga kader dapat terus memberikan pelatihan kepada masyarakat yang lain tentang hipertensi serta pengendaliannya.

\section{PEMBAHASAN}

Ascariasis merupakan infeksi cacing yang paling sering ditemui. Diperkirakan prevalensi di dunia 25 $\%$ atau 1,25 miliar penduduk di dunia. Biasanya bersifat symtomatis. Prevalensi terbesar pada daerah tropis dan di negara berkembang dimana sering terjadi kontaminasi tanah oleh 
tinja manusia atau penggunaan tinja sebagai pupuk (Soegijanto, 2005).

Ascaris lumbricoides merupakan nematoda kedua yang paling banyak menginfeksi manusia. Ascaris telah dikenal pada masa Romawi sebagai Lumbricus teres dan mungkin telah menginfeksi manusia selama ribuan tahun. Jenis ini banyak terdapat di daerah yang beriklim panas dan lembab, tetapi juga dapat hidup di daerah beriklim sedang.

Askariasis adalah penyakit parasit yang disebabkan oleh cacing gelang Ascaris lumbricoides. Askariasis adalah penyakit kedua terbesar yang disebabkan oleh makhluk parasit.

\section{KESIMPULAN}

Penderita cacingan akan mengalami penurunan daya tahan tubuh serta metabolisme jaringan otak. Bahkan, dalam jangka panjang, penderita akan mengalami kelemahan fisik dan intelektualitas. Kategori infeksi cacing ditentukan dari jumlah cacing yang dikandungnya. Jika anak-anak itu sudah terinfeksi cacing, biasanya akan menunjukkan gejala keterlambatan fisik, mental dan seksual. Infeksi usus akibat cacingan, juga berakibat menurunnya status gizi penderita yang menyebabkan daya tahan tubuh menurun, sehingga memudahkan terjadinya infeksi penyakit lain, Tuberkulosis dan Malaria. Minuman yang tercemar telur-telur cacing. Umumnya, cacing perut memilih tinggal di usus halus yang banyak berisi makanan. Meski ada juga yang tinggal di usus besar.

Pengendalian penyakit cacingan dapat menurunkan prevalensi dan intensitas penyakit cacingan sehingga dapat menunjang peningkatan mutu sumber daya manusia, guna mewujudkan manusia yang sehat. Program pemberantasan cacingan menghasilkan perbaikan besar baik bagi kesehatan perorangan maupun masyarakat, yaitu :

1. Dengan bebas penyakit cacingan produktivitas meningkat.

2. Dengan berprilaku hidup bersih dan sehat, kita bebas penyakit cacingan.

3. Penyakit cacingan hilang dan prestasi meningkat.

\section{DAFTAR PUSTAKA}

Berhman RE, Kliegman RM, dan Arvin AM. 1999. Ilmu Kesehatan Anak Nelson. Editor edisi bahasa Indonesia A. Samik Wahab. Edisi 15. Volume 2. Jakarta: EGC.

Ganda, Husada. 2000. Ilmu kesehatan anak dan kesehatan. Editor bahasa indonesia

A.Samik Wahap.Hal.30.Jakarta: EGC

Hendrawan. N, 1997. Infeksi Cacing, Raneka Cipta, Jakarta. 
Madanijah, S. 2004. Pendidikan Gizi dalam Pengantar Pangan dan Gizi. Jakarta: Penebar Swadaya

Majid, A, 2011. Mencegah Jangkitan Cacing. Pusat Racun Negara, USM.

Oeswari,1991. Buku ilmu gizi kesehatan dan anak. Cetakan 1.Hal.53.Surabaya : Airlangga University Press.

Rudolph, Abraham M. dkk. 2006. Buku Ajar Pediatri Rudolph. Editor edisi bahasa Indonesia A. Samik Wahab. Edisi 20. Volume 1. Jakarta : EGC.

Soegijanto, Soegeng. 2005. Kumpulan Makalah Penyakit Ttopis dan Infeksi di Indonesia. Cetakan 1. Surabaya : Airlangga University Press.
Soegijanto, Soegeng.2005.Kumpulan Makalah Penyakit Tropis dan Infeksi di Indonesia Jilid 4. Surabaya : Airlangga University Press

Viqar Z., Loh AK, 1999. Buku Penuntun Parasitologi Kedokteran. Penerbit Binacipta.

Zit Z, 2000. Pengobatan Infeksi Cacing yang Ditularkan melalui Tanah dengan kombinasi Mebendazol dan Pirantel pada anak, Majalah Kedokteran Sriwijaya. 32 (1). 46-50 